\title{
Erratum: The role of church youth in the transformation agenda of South African cities
}

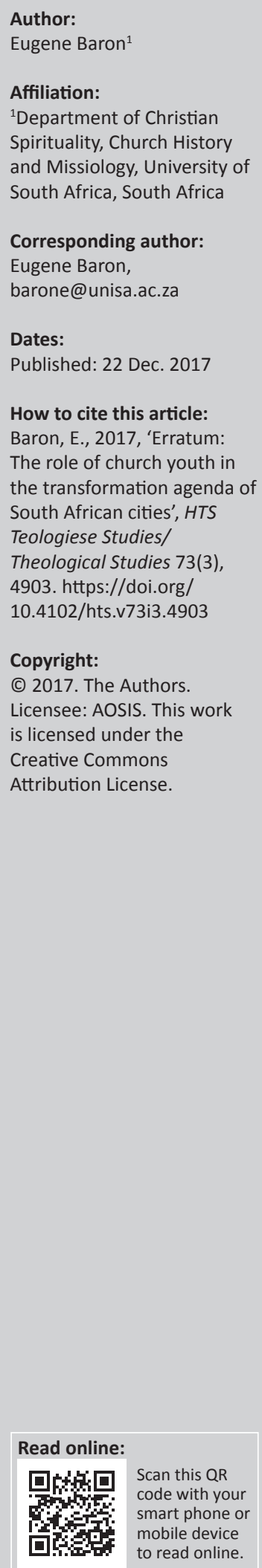

In the version of this article initially published, the incorrect funding information was acknowledged in the note. The note is hereby corrected and updated as: 'This article forms part of a collaborative research project entitled "Religious innovation and competition amidst urban social change: A Pretoria case study." The project was funded by the Templeton Foundation as part of an African-wide enquiry on "Christianity and social change in contemporary Africa." The project is also a sub-theme of the "Faith in the City" research project, hosted by the Centre for Contextual Ministry in the Faculty of Theology, University of Pretoria'. This correction does not alter the study's findings of significance or the overall interpretation of the study results. The editor apologises for any inconvenience caused. 


\section{The role of church youth in the transformation agenda of South African cities}

Author:
Eugene Baron ${ }^{1}$
Affiliation:
'Department of Christian
Spirituality, Church History
and Missiology, University of
South Africa, South Africa
Corresponding author:
Eugene Baron,
barone@unisa.ac.za
Dates:
Received: 14 Aug. 2017
Accepted: 05 Sept. 2017
Published: 19 Oct. 2017
How to cite this article:
Baron, E., 2017, 'The role of
church youth in the
transformation agenda of
South African cities', HTS
Teologiese Studies/
Theological Studies $73(3)$,
mobile device
to read online.
a4771. https://doi.org/
10.4102/hts.v73i3.4771
Copyright:
@ 2017. The Authors.
Licensee: AOSIS. This work
is licensed under the
Creative Commons
Attribution License.

The churches in City of Tshwane have incredible youth capital. There is so much energy and passion that fill the concrete walls of the mushrooming churches. This article emerges from a research that was conducted to explore religious innovation and competition amidst demographic and social change among churches in the City of Tshwane. The data of the study suggest that the impetus behind most of the innovation and development in the churches is borne from the hearts and minds of the young people. The striking involvement of the youth in the congregations, their participation and also the reflection in the data in terms of youth agency highlight the concern on their involvement in urban, social change, with specific reference to the City of Tshwane. The article assesses the participation of the church youth in the transformation of the city.

\section{Introduction}

In 1976, the youth of Soweto took the bigger agenda of non-racialism to the streets. In a postapartheid South Africa, in 2016, the bigger agenda of poverty was also taken to the streets of various universities, where the youth protested for free education. The police had their hands full with the protesting students, which in some cases led to a militarised presence of the police at most residential universities in South Africa. This got also the executive branch of government involved in the matters of public university students. It forced the top echelons in government to engage with the most vulnerable in society; students struggle to make financial ends meet. Although the way in which these young people conducted themselves might raise concern, the fact that they were able to take part in the transformation agenda that would impact the broader society is significant. These two events in history have some similarities, though epochs apart.

The City of Tshwane, like most South African cities, has become a space of contestation for resources, a display of poverty of the most vulnerable in society and, indeed, a visible struggle for survival. The urban environment has its own, unique challenges that stifle growth and prosperity for all citizens in the city. One of the issues in the City of Tshwane is homelessness. The issues relating to homelessness have become an ongoing discussion of which some theologians of the University of South Africa joined. In a community engagement project of the Department of Christian Spirituality, Church History and Missiology, the said theologians conducted contextual bible studies, had fellowship and had a meal with the homeless people. Through the encounter with the homeless people a series of publications ${ }^{1}$ emerged which focus on issues that directly emerged from the contextual bible studies. The publication itself focused on some of the issues that originated from the data of the bible studies, which include inter alia issues related to migration, housing, human dignity, justice, poverty and also other issues that emerged as part of the ongoing project. Another scholarly contribution was made in 2014 by a group of theologians, with Swart and De Beer as project leaders, engaging social issues that manifest in the urban environment of Tshwane. ${ }^{2}$ In their article in which they introduce some scholarly contributions, they also invite and encourage theologians at large to focus on social challenges pertaining to the urban environment. Their concern is in the context of the worrying picture that the National Planning Commission (n.d.) observes:

South Africa's towns and cities are now home to more than 60 percent of the national population and account for 80 percent of economic activity ... with these percentages expected to increase. The future of the

1.In 2014, colleagues from the Department Christian Spirituality, Church History and Missiology released a book with eight articles entitled Pavement Encounters for Justice (2014) that addresses the issues relating to homelessness in the City of Tshwane.

2.Swart and De Beer (2014) introduced a collection of articles which they argue will contribute to a rather new (now 3 years back) agenda of doing theology that is aimed at issues related to the urban environment. The authors introduced a special collection on 'Doing urban public theology in South Africa: Visions, approaches, themes and practices towards a new agenda' in HTS Teologiese Studies/Theological Studies, Volume 70, Issue 3, 2014.

Note: The collection entitled 'Spirit rising: tracing movements of justice', forms part of the 'Faith in the City' research project, hosted by the Centre for Contextual Ministry in the Faculty of Theology, University of Pretoria. Some of the articles were papers presented at the Biennial Consultation on Urban Ministry, hosted by the Institute for Urban Ministry, in collaboration with other organizations, from 17-20 August 2016. The theme of this Consultation was '\#We must rise: healers-dreamers-jesters'. 
urban centres is of enormous importance to national development. Rapid urbanisation has exacerbated all of the socioeconomic challenges that were already present, from widespread poverty to alarming levels of youth unemployment and infrastructure backlogs. It is possible that by 2025, the country's urban areas will be bigger, poorer, more congested, more polluted and more socially fractious.

Nevertheless, the research of academics from nearby Universities, ${ }^{3}$ launched in 2016, was another study that focused on issues in the City of Tshwane. The research by these scholars paints more or less the same picture than the one provided by the National Planning Commission. However, the focus was specifically on the religious atmosphere and contestation in the City of Tshwane. In 2012, De Beer (2012) articulates his diagnoses of the religious atmosphere in the City of Tshwane:

Driven by the spirit of consumerism, city dwellers are confronted with alternatives to almost everything - socially, politically, economically and religiously. That is why, on a spiritual front, city dwellers hop from one church to another shopping around for what is best for them; as such they often prefer to be free riders in any institutional church, rather than disciples. Their choices are diverse and varied, namely: (1) African Initiated Churches occupying open spaces for worship in the city; (2) independent Pentecostal groups gathering in shopfronts, museums and school halls; (3) traditional mainline churches; (4) suburban churches; (5) township and informal settlement churches; (6) mega-churches; and (7) the emerging e-church movement of those who are going virtual and viral. (pp. 258-259)

This study, namely religious innovation and competition amidst demographic and social change among churches in the City of Tshwane, also focused on the urban environment and its social issues, but was particularly interested in how the churches respond to those social issues. Swart and De Beer (2014) highlight the importance of the church in addressing issues in the city. They observe:

\begin{abstract}
... we are [also equally] in agreement with them [Graham \& Scott $2008]^{4}$ regarding the fundamental practical theological dimension of the task ahead of us, which should prioritise a concern with the agency role of church and other religious communities - albeit not in isolation from a concern with the agency role of other actors in the city and spaces of the urban such as the state and groups and associations in civil society - in the struggle for 'more habitable, more sustainable ways of living in the city'. (p. 2)
\end{abstract}

This study (2016-2017) was therefore in line with the proposed agenda by Swart and De Beer (2014), in assessing the role of the church in the City of Tshwane, and in terms of its participation and agency related to the social challenges in the urban environment.

The findings of this study demonstrate that the church has its own way of dealing with issues of migration, urbanisation

3.There are also other ongoing academic, research projects focusing on issues in the City of Tshwane, but these are specifically known to me. The third project that is mentioned is the one that provided the data for the article. The project was sponsored by donors outside of South Africa in which various colleagues in academi the University of South Africa (UNISA), as well as the University of Pretoria (UP).

4.They largely base their argument on the role of the church in cities on the work of Graham and Scott (2008) and other societal challenges. ${ }^{5}$ This article will not draw on all those responses that are part of the findings of this study. However, this article will particularly draw on some striking, interesting and significant results that concern the youth in the various churches (also referred to as focus groups in this article) that participated in this study. The findings show interesting results in terms of the church youth's experiences, as well as the churches' utilisation of them, and how this relates to the agenda of transformation in the City of Tshwane. I am particularly interested in how the church youth fits into the broader response and framework of the church in changing and responding to urban challenges and in relation to this I pose the question: How does the church youth respond amidst demographic and social change in the City of Tshwane? Subsequently, how can the church utilise the youth in serving the agenda of transformation in the City of Tshwane? In an attempt to respond to the above questions, I will answer three related questions:

Firstly, what is the purpose of the church? Secondly, can the church play a role in the social transformation in an urban, city context? And thirdly, where does the church youth fit into the broader scope of the church's role in the city context? This study will briefly address these questions in arguing for the inclusion of the church youth in the broader agenda of social transformation in the City of Tshwane.

\section{The missional nature of the church}

The church's purpose is not only for the edification of believers and its congregants but to take part in what the triune God is doing in the world. The discussion around the participatory role of the church in society is part of the conversation of 'missional church'. ${ }^{6}$ The church is in its nature missional, because it is understood to be 'a community of witness, called into being and equipped by God, and sent into the world to testify to and participate in Christ's work' (Niemandt 2012:1). The South African theologian H. Jurgens Hendriks (2007) joined such voices, and he outlines missional principles that he believes is important for doing theology in Africa. According to Hendriks (2007), faith communities will always have to be in reflective engagement with the world. He asserts that the church:

will never deign to give anyone a blueprint about being church, but it will provide a methodology to discern how to participate in the missional praxis of the Triune God and, as such, how to become what God wants his people to be: his image, his body. (p. 1004)

H. Jurgens Hendriks (2007) captures the underlying assumption on which the whole endeavour of doing theology

5.The findings on the churches' response in terms of various societal issues are included in other scholarly contributions and publications that are based on this research project that was launched in 2016 and ended at the end of the first quarter of 2017.

6.The term 'missional church' gained prominence after the release of the book edited by Guder and Hunsberger (1998) Missional Church: A Vision for the Sending of the Church in North America. The movement that primarily influenced the thoughts on Missional Church is the Gospel and Our Culture Network and the Partnership fo Missional Church. Others include the works of Lesslie Newbegin and David Bosch that from a theological perspective engage the philosophical and epistemologica roots of modernity, of Western and Reformed theology and Culture. However, in South Africa is the Network for African Congregational Theology (NetACT) of which $\mathrm{H}$. Jurgens Hendriks was part. 
rest. He uses the symbol of the Kingdom of God to express how the church should act in the world:

It [the symbol of the Kingdom of God] points to the belief in a Triune God who created the world and acts in this world for the benefit of its people. In Jesus Christ the Kingdom became flesh and blood. His life and death and resurrection are intrinsically linked to the creative motive, because in his death and resurrection one finds re-creation, a new creation dawning upon us. Jesus' life and teaching teach us that the Kingdom of God is approaching and that it brings salvation. This is good news for all, especially the poor, the weak, outcast, the unjust and sinners. It is a dream about the future that invites us to improve our present reality and, as such, is linked integrally to the process of doing theology. (p. 1018)

Hendriks' description of how the church should do theology is well illustrated above - through the Triune God, bringing the good news of the Kingdom of God to all on earth. The church plays a vital role in the shaping, reshaping and transformation of communities. Van Wyk's (2017) findings illustrate that deliberate and intentional actions by churches allow them to become a voice for the marginalised, to create spaces for searching for excellence and to increase the quality of servant leadership. In doing so, he argues that the church will be able to act as a vehicle for transforming church society. Van Wyk (2017) takes the role of the church seriously and compares it to the work of the 1500s' reformationists:

These reformists were the voice-of-the-voiceless and protested against bribery, corruption and dishonesty in the early Church. These reformists - Luther in particular - used the Bible (Holy Scriptures) as their most commanding and authoritative tool in engaging the devoted followers of the church to break from the Roman Catholic Church. (p. 2)

Van Wyk's contribution indeed speaks to the transformation of church and society. It is evident through the servanthood of those reformers in the 1500s that not only the church was taking on new shape, but it also brought reforms to the societies and contexts that they and their ideas influenced. Samuel (1999:227-235) discusses the role of the church as an agent of transformation. He argues that the church should still be involved in evangelism, but that it should not exclude the welfare of the society and community it serves. He (1999:228) recognises the tension between the two (evangelism and welfare) and argues that one has not to choose between the one and the other, because he is convinced that the two can be seen as 'two wings of the same bird or parallel tracks of the same railway'. The role of the church in society has also reference to those living in the urban settings. The following section will highlight such a role by churches.

\section{The role of the churches in social transformation in the city}

In the discussion above, I referred to the priority that some theologians have given to social issues in the context of the City of Tshwane. Cities have many social challenges that need to be addressed. The survey of this study shows that there is an estimate of 100-200 churches in the City of Tshwane. The amount of churches is indeed significant and reflects the space that churches occupy in the city. The statistics also reflect the attendance of citizens in these churches.

However, to assess the involvement of the churches of Tshwane in social issues, the researchers had to do further analyses, which included two World $\mathrm{Cafes}^{7}$ as well as focus group discussions with some of the churches that gave permission for further in-depth discussion conducted at their local church. The data do not illustrate much of the involvement and participation of the churches in social transformation of the city. This is indeed the sad reality and goes against the understanding of the church as being missional.

Van Gelder (2008:60) argues that there should be a relationship between the city church and the issues and challenges of the city. Van Gelder (2008) explains the 'city' as

... our place of residence: we live, work, and dwell in the city. Of course, the geographic and demographic makeup of our communities varies widely. But unless we find ourselves solitary on a desert island, we are part of a community where we (usually) benefit from one another. From law enforcement and firefighting to markets and hospitals, we live in communities where we share the same values of how to live together. (p. 60)

Van Gelder (2008) observes that Golgotha (the outside of the city) and the City of Jerusalem (where God's people gather) are closely linked. He states:

Jerusalem and Golgotha are inextricably linked. Jesus is condemned in the city by the powers and principalities, and he is subsequently marched outside Jerusalem's gates to be crucified. This close proximity points to the important relationship between the city and the crucified. Our journey to the crucified is within walking distance, and we readily offer our praise to God through Christ (Heb. 13:15) within hearing distance of the city. (p. 60)

Here I wish to also point to the perspective of Van Gelder (2008:60) that the worship of the church is central to prepare the church for its involvement and reaching out to the cities in which they live. He (2008) states:

In worship we learn what is good; we are consecrated and perfected in terms of the conscience. Worship creates the space where the city's [church] seemingly orderly walls and the messiness of Golgotha [other geographic cities which we live] meet, and in this space we learn to do good and the share what we have (Heb. 13:16). He goes further, From our encounter with the crucified one, we are sent to 'let mutual love continue' (Heb. 13:1), 'to show hospitality to strangers' (Heb. 13:2), and to 'remember those who are in prison' and 'those who are being tortured' (Heb 13:3). (p. 63)

The above discussion of Van Gelder is well in line with the way in which church life stimulate and inspire the values and

7.See the work of Fouche and Light (2010) in their article An Invitation to Dialogue 'The World Café' In Social Work Research' which is available on the following website: http://journals.sagepub.com/doi/abs/10.1177/1473325010376016. The website: http://journals.sagepub.com/doi/abs/10.1177/1473325010376016. The World Cafe method they indicate is a conversational process that helps groups to engage in constructive dialogue around critical questions, to build persona relationships, and to foster collaborative learning'. In relation to other collaborative approaches, the World Café is powerful in terms of the use of cross-pollination of ideas through evolving rounds of information exchange and the use of a café-style social context that allows the sharing of information in an equitable and nonthreatening manner. 
morality that is necessary to transform the life of our neighbours, those living in our cities. The churches that participated in this study report on the challenges that they and their 'neighbours' are experiencing in the city. The churches and participants did report on issues such as unemployment, poverty, challenges of physical space, lack of housing, crime, shebeens, teenage pregnancy and few others. However, the churches do not show involvement and engagement within those issues and sad realities. There is not even a sign of them participating or engaging in the policymaking processes and dialogue with the government, at least not what their church structure and functions allow.

The South African missiologist, Derrick Mashau (2014:4), takes the discussion further than Van Gelder, within his focus on transformative encounters in the church, and addresses the role of the church in the midst of political power and exploitation of the most vulnerable in the City of Tshwane. He argues that the political powers are responsible for the challenges that the City of Tshwane is faced with. Mashau (2014) argues that to engage the centres of power (which he refers to as the metaphorical hills in Tshwane - as most of those centres of power are geographically positioned on the hills of the city), the church has to be missional in nature. This means that the church has to:

encourage all of its members (evangelists, educators, counselors, business people, environmentalists, and advocates for social transformation among others) to serve in all forms of mission engagement where God called and placed them in this life. (p. 4)

\section{He states:}

Mission [thus] becomes the DNA of every Christian, thereby reclaiming space for the office of believer in all institutional churches. You are therefore busy with mission when you are preparing dinner for your family, assisting your children with their homework, or ministering to your colleagues at work who need a word of advice or ask for counselling. You are busy with mission when you speak on behalf of the voiceless and the marginalised in society. And yes, you are busy with mission when you are taking care of God's creation. In essence, the church of God is busy with mission when we become the hands and feet of Christ in advancing his reign here on earth. (p. 4)

The 'hands and feet of Christ in advancing his reign here on earth' is what the churches in the City of Tshwane have to step up. Without labouring the issue of the role of the church in the city, it is crucial to underline that the cities would be able to socially transform through the visible presence, involvement, participation and contribution of the churches in the city.

Mashau (2014) lists a few pointers for churches for change in City of Tshwane, which I deem very appropriate for the hypothesis of this article:

Christian mission should serve as agents of transformation by bringing God's shalom and justice into the city context as they intentionally engage the social ills and economic and political powers in the City of Tshwane. Providing shelter for the homeless, transferring skills to empower those on the margins to access jobs, collaborating with government and private institutions to fight poverty, joblessness and inequality, and advocacy can be cited as some of the practical things that churches can do in and with the community. (p. 10)

God helps by prompting us to embrace a spirituality that is intrinsically transformative. The landscape of worship in the city context should therefore be transformed from being consumeroriented to God-oriented. Our worship (singing, praying, preaching, sacraments, etc.), meditation, praying and fasting should constitute the spirituality for mission encompassing the spirit of transforming encounters. The prophetic voice will in this instance never be missing from our worship services; indeed, worship will become a way of life instead of a once-off event on Sunday. (p. 10)

It is clear in Mashau's proposals that the church should be more than spaces for 'personal upliftment' or 'entertainment'; it should be a place of transformative encounters, which will also overflow into bringing transformation and 'God's shalom and justice' to the city.

So far, this article has argued that the church has a role to play in the transformation of urban communities. Although the focus in this article clearly advocates the role of the church as being missional in nature and addressed the challenges faced by citizens in the urban setting, it is also important to emphasise the role of the youth in the confines of the church. The churches can do much to increase the agency of the youth in the transformation of the city. The next section will engage in this discussion.

\section{The inclusion of the youth in the church's missional agenda}

Although it is argued in this article that the church has a responsibility towards society, it should not exclude the church youth, which forms part of the church participating in God's mission on earth. This is not often the case as the youth in the church is at times only good for church activities, through taking part in the Sunday worship and the various ministry departments in the church. The churches in the City of Tshwane also intentionally overlook these young people in terms of equipping them for participation and mobilising them as agents of change in society.

Nel (2015) argues that the church should make young people disciples that will continue to make disciples. He observes that children are part of the disciple-making process, not just adults. This, however, should be a conscious and intentional process. He cautions that this does not mean that the youth should only be taught about God (Nel 2015). In fact, Folmsbee (2007:39) suggests that discipleship is not solely about learning more about God, but how to live one's life to glorify God. Therefore, he argues that the church should help their youth to:

- celebrate inclusion

- celebrate learning how to live life

- celebrate developing (however challenging) a sensitivity to choose what matters most in life. 
The church should be intentional in preparing the church for the various communities, rural and urban communities of which it forms part off. The youth should equally be part of challenging the powers that $\mathrm{be}^{8}$ and also be inspired through the church activities to transform the lives of their neighbours. ${ }^{9}$ Cloete (2012:6) emphasises the role of faith communities in the education of youth in terms of the HIV and AIDS pandemic that is threatening South African communities. This is indeed one of the ways in which the church might be involved in education as well as mentoring youth towards active participation and prevention of issues such as the said pandemic. Although this might be the case in some of the churches that is located in the City of Tshwane, the data do not reveal any such explicit, intentional processes as part of the churches' structures that inspire and encourage youth participation and active involvement towards social transformation in the city.

Linhart (2014) argues that youth work should be community centred:

Youth workers build a programme in the local community, from drop-in-centres, sports leagues and tutoring to various clubs, and then work to meet the needs of young people, building community with and within the local context. (p. 182)

He also refers to the words of Shepherd (2011:35; in Linhart 2014:182), who observes that community 'is at the heart of mission, because community is central to the very nature of God as Trinity'. At the core of his argument is the church youth's participation of church in transforming the lives of those communities they are part, as well as participating in projects of social transformation.

It was picked up in the data of one of the churches that the church youth is often perceived by leaders in the church as not matured and naïve to the social challenges in the city. This could be a way of excluding the youth in being agents of change in the social affairs and challenges in the city.

Bowers Du Toit's (2014) article provides a good response in terms of the situation that is experienced in some churches in the City of Tshwane. She focuses on the agency of youth in the midst of gangster violence on the Cape Flats. She offers a response to the gangster-related violence by pointing to the role of the church in addressing the 'powers' 10 in the community on the Cape Flats. In her argument, the youth lies at the heart of what is happening and is often lured into the practices of those involved in gangsterism. In response to the systemic evil and violence through gangsterism on the Cape Flats, Bowers Du Toit focuses on the role of the church ${ }^{11}$ in the lives of young people in their area. Bowers Du Toit argues that the church cannot distance her, but should in fact 'engage

8.See above the discussion of Mashau (2014) and his remarks on the church to challenge the powers in the City of Tshwane.

9.See above the remarks of Van Gelder (2008) on the church transforming the lives of their neighbours.

10.Bowers Du Toit uses the work of Walter Wink and his theory on systemic powers in the world.

11.It is apparent in her response that she focuses on the institutional church. the powers' (which in her case specifically refers to gangsterism). ${ }^{12}$ The church should 'subvert the powers', proclaim the 'fallenness of the powers', 'modelling Kingdom ethics to children and youth', 'prayer as resistance', as well as 'the power of solidarity and hospitality'. It is apparent in Bowers Du Toit's response that the church should do more than just be an institution for themselves but should be involved in social issues (like gangsterism and other social ills) than is hampering the prosperity of society. What is quite interesting in her response to the gangster-related violence is her perception of the youth, other than those involved in gangsterism. This is different than some of the negative perceptions of young people that they are not 'mature enough' (as if they will never be mature enough) and 'not ready' (as if they will never be ready as long as they stay youth) to confront, participate and engage societal issues. Despite such perceptions, Bowers Du Toit argues that the youth should play a role, alongside the church, to address the social ills.

Given the discussion above, I will specifically report in the next section on the data in relation to one of the questions that was posed to the focus groups on how do they perceive youth agency. However, the discussion will also go broader than this and discuss the researchers' observations and their experiences of the youth during the focus group discussions. This will allow me to draw some final conclusions and recommendations on the role that church youth currently play and might play within the structures of the churches in the City of Tshwane.

\section{Discussion on the data}

The researchers reported the involvement and participation of the church youth in the focus groups and that their level of involvement was more than the older members of the congregants (F1). ${ }^{13}$ The youth, for instance, reported among others, of their involvement in 'home-to-home visitation every Thursday of the week' (F1). The data do not only underscore their involvement and participation of church events but also of taking responsibility and initiative for the planning of core events of the church. Besides their active involvement, these young people demonstrate that they are very much part of the innovative ideas in the church (F2). The data illustrate that these young people are part of various items of the worship services like the 'praise and worship' at the onset of the service. They therefore subsequently state that they 'enjoy[s] the flexible adaptations made in the liturgy', as well as the song selection (specifically in terms of style and vernacular) (F2). The modern style of worship 'adaptations' is always through the blessing of the leadership of the church, and therefore, they are excited to be part of new expressions and structuring of the worship services. How successful it is may differ from a range of variables;

12.She makes reference to Walter Wink (1992:82) who observes, Christ came to proclaim to the powers the advent of the kingdom of God, which 'would transform every aspect of reality, even the social framework of existence'

13.Please note that the codes (F1, F2 etc.) are used to conceal the identity of the particular church from which the data came. Therefore, F1 may represent a particular church from which the data was extracted. 
however, the point is made that the young people within the churches has the capacity to be innovative and thinking in new ways to transform the way the worship services of the churches are being structured.

Although the focus groups were requested by the researchers to be diverse in terms of gender, age, race and other demographics, the focus groups at the end comprised of congregants whose ages ranged between 21 and 35, which can relatively be classified as youth. It seems this category made up the majority in terms of the type of participants that were involved in the focus groups. ${ }^{14}$ It also seems as if these young people were the ones that were easily accessible, as well as more flexible to participate in the research, and in some cases, it seems that the contact persons find it a bit difficult to have recruited older participants.

In the one focus group the researchers report of a $60 \%$ attendance of young people during their worship services (F1). The one group also discussed the likelihood of young people coming from rural township churches and moving to the city, then joining those churches which worship services are 'lively' [sic] (F1:10). This is how one of the young people in a focus group responded:

\begin{abstract}
... so a lot of young people tend to move to church[es] like that because [we already said that] you have young people moving into the city [when they go] home where they come from, they usually go to the traditional churches, but when they come to Pretoria they have an opportunity to go elsewhere so they prefer to go there [those churches which worship services are lively] instead. (F1:10)
\end{abstract}

In speaking of the dynamics of the church of which the youth are members - they refer to the freedom they have as youth, for instance, to have an opportunity to talk about issues (for instance sex) that they were not able to talk about in their rural churches back home (F1:11). They feel that the church in the city is more open towards change in terms of the liturgy of the church, as well as the way the church in the city is structured. One of the focus groups, which comprised mostly of young people echoes, 'maybe the change is that people are moving with the times ... do I still want to do what my grandmother was doing 17 years [ago?] maybe people are moving with times' (F1:12). The youth attest to the openness and flexibility of the church, to allow them latitude to be themselves and introduce new ways of doing church.

The data also reflect the role that the young people play in terms of the congregational structures and activities:

We want our church to move with the times but why are we finding ourselves within [F1] $?^{15}$ There are those who were saying let's keep it the way it was. [why do] I want to come to the very same church that will remind me of my grandmother where I will see the way this church used to be. People come here and they complain about certain things that were done to accommodate them moving at times and things but people are

14.The amount of young people varies, however, F3 (focus group) was $99 \%$ young people using the classification above.

15. Note that the codes (F1, F2 etc.) are used to conceal the identity of the particular church from which the data came. still complaining saying I'm going to leave this church because this church $[i s]$ so relaxed I [can] see this happen[ning]. We want to move. It could be a certain portion that wants to move with the times but there are those please keep the church rigid. (F1:12)

Young people convey their agency in the church through their involvement in the church council and believe through their participation in the decision-making body of the church - things will change (F1:13). But they also speak of the inclusion of children, women and people with homosexual orientation in the church, which are welcome in the church (F1:13). There is so much freedom in the church for them (for instance, women allowed to wear trousers, and boyfriend and girlfriend can hold hands). The young people are well aware of the struggles and challenges people face in the city in which they stay and articulate in their response their sympathy.

There also seems to be a 'political consciousness' among the youth in the church. Although the young people in the focus groups did not explicitly articulate it, it becomes clear through the transcripts on the issues and themes that they address during the discussions, that they want to see social transformation in the city. ${ }^{16}$

When the young people in one of the focus groups (F1) were given the opportunity to say what they are doing outside the walls of the church, there response shows clearly that they felt helpless: '... they [homeless people] are hungry but you can't even help them that are a challenge as a Christian you believe that you should help but when you can' $t^{\prime}$ (F1:15). The youth do not see other alternatives and ways in which they can make a difference. They feel the need to help and assist with current challenges that citizens in the city faces, but lack concrete ideas and also inspiration from church leadership.

The responses from the young people show their commitment towards change within the structures of the church, but it also shows their commitment to move with the 'times'. That young people that were part of the focus groups are well informed on the challenges that are apparent in the city is evident. In fact, in some cases, most of the responses in terms of an assessment of social diagnostics and to determine what is wrong in the city came from the young people in the churches. It was young people that made up in some of the focus groups almost half or more than half of the participants. It shows their awareness and simultaneously also their concern for social transformation.

What concerns involvement - the data reflect much involvement of the youth in the activities of the church, being at times the driving force behind innovative ideas and suggestions that steer the church towards qualitative growth. However, when responding to the question of youth agency, one of the leaders of the church was quite reserved in terms of the participation of the church youth in what was termed 'political matters'. The above is a short reflection of what one 16.See the questions of the facilitator: 'some of the comments have been dealing with matters inside the congregation but if you look outside the congregation ...' (F1: 14). 
can glean from the responses and observation of the researches during the focus group discussions.

\section{Conclusion}

It is evident in the analysis of the data that the youth are active and show deep involvement in the activities and affairs of the church. The question 'How does the youth respond amidst demographic and social change in the City of Tshwane?' is been answered through the analysis of the data obtained from the focus groups discussion. In those discussions, it became clear that the youth have an awareness of the social changes in the city and show a 'political consciousness'. It shows agency of the youth in the confines of their own congregation, but not much involvement and participation in the social agenda of the city. The youth with their vigour and innovative ideas filling the walls of the churches in the city are not encouraged through their church structures to 'take the social agenda to the streets' of Tshwane. The youth's response is within the church walls and not in the streets of Tshwane.

Although much has been said by the academics and missiologists alike on the mission of the church, the study places once again the agency of youth in the transformation of the city on the agenda. Churches should identify the youth capital in their respective congregation and encourage the youth to join the mission of the triune God in the transformation of our cities in South Africa.

\section{Acknowledgements Competing interests}

The author declares that he has no financial or personal relationships which may have inappropriately influenced him in writing this article.

\section{References}

Bowers Du Toit, N.F., 2014, 'Gangsterism on the cape flats: A challenge to "engage the powers"', HTS Teologiese Studies/Theological Studies 70(3), Art. \#2727, 1-7. https://doi.org/10.4102/hts.v70i3.2727

Cloete, A., 2012, 'Youth culture, media and sexuality: What could faith communities contribute?', HTS Teologiese Studies/Theological Studies 68(2), Art. \#1118, 1-6. https://doi.org/10.4102/hts.v68i2.1118

De Beer, S., 2012, 'Urban South Africa: An opportunity for liberating theological education', Missionalia 40(3), 251-277.

Folmsbee, C., 2007, A new kind of youth ministry, Zondervan, Grand Rapids, MI.

Fouché, C. \& Light, G.L., 2010, 'An invitation to dialogue "The World Café", in Social Work Research', viewed 14 September 2017, from http://journals.sagepub.com/ doi/abs/10.1177/1473325010376016

Graham, E. \& Scott, P.M., 2008, 'Special issue - Public theology and the city: Urban theology as public theology', International Journal of Public Theology 2(1), 1-6. https://doi.org/10.1163/156973208X256411

Guder, D.L. \& Hunsberger, G.L., (eds.), 1998, Missional Church: A vision for the sending of the church in North America, W.B Eerdemans, Grand Rapids, MI.

Hendriks, H.J., 2007, 'Missional theology and social development', HTS 63(3), 1000-1018. https://doi.org/10.4102/hts.v63i3.244

Linhart, T., 2014, 'Mission', in S. Nash \& J. Whitehead (eds.), Christian youth work in theory and practice, pp. 176-191, SCM Press, London.

Mashau, T.D., 2014, 'Reimagining mission in the public square: Engaging hills and valleys in the African City of Tshwane', HTS Teologiese Studies/Theological Studies 70(3), Art. \#2774, 1-11. https://doi.org/10.4102/hts.v70i3.2774

National Planning Commission, n.d., The future of towns and cities, viewed 07 April 2014, from http://www.npconline.co.za/pebble.asp?relid=192

Nel, M., 2015, 'Imagine-making disciples in youth ministry ... that will make disciples', HTS Teologiese Studies/Theological Studies 71(3), Art. \#2940, 1-11. https://doi. org/10.4102/hts.v71i3.2940

Niemandt, C.J.P., 2012 'Trends in missional ecclesiology', HTS Theological Studies 68(1), 1198. https://doi.org/10.4102/hts.v68i1.1198

Samuel, V., 1999, 'Mission as transformation', in V. Samuel \& C. Sugden (eds.), Mission as transformation. A theology of the whole gospel, Regnum.

Shepherd, N., 2011, 'Community builder', in S. Nash (ed.), Youth Ministry: A multifaceted approach, SPCK, London.

Swart, I. \& De Beer, S., 2014, 'Doing urban public theology in South Africa: Introducing a new agenda', HTS Teologiese Studies/Theological Studies 70(3), Art. \#2811, 1-14. https://doi.org/10.4102/hts.v70i3.2811

Van Gelder, C. (ed.), 2008, The missional church \& denominations: Helping congregations develop a missional identity, WB Eerdmans, Grand Rapids, MI.

Van Wyk, M.M., 2017, 'Exploring the role of the church as a "reformation agency" in enhancing a socially transformative agenda in South Africa', HTS Teologies Studies/Theological Studies 73(3), a4356. https://doi.org/10.4102/hts.v73i3.4356

Wink, W., 1992, Engaging the powers: Discernment \& resistance in a World of Domination, Fortress, Minneapolis, MN. 